\title{
Financing options for businesses in Ireland
}

\author{
Jane Power \\ College of Business and Law - Department of Economics, UCC
}

\section{Introduction}

Starting a business is a complex process which requires multifaceted organisation and planning. Entrepreneurs begin with an idea which must immediately be tempered with the need to justify the creative concept, choose the business location, assess the competition and, most importantly, identify methods to finance it. This last task is the most crucial as, without capital, there will be no business. The majority of entrepreneurs face one fundamental problem; they rarely have the amount of capital required to see their ideas to fruition. Creating a business and executing a business plan requires finance. Given the global credit-crunch, it is pertinent that funding options available to entrepreneurs are investigated. An entrepreneur has numerous sources of finance to choose from. These range from funding provided by family or friends to various sources of debt and equity finance.

This research aims to explore the financing of businesses in Ireland, to provide a more in-depth understanding of the sources of financing utilised. The study is currently at the data collection phase, gathering information on the types of finance utilised by businesses throughout Ireland.

\section{Financing Options}

In the current economic climate the flow of innovative start-ups into the economy is critical for future growth. However, the establishment and expansion of these innovative businesses requires finance. Raising the necessary capital is crucial. In an economic climate where funding has become increasingly scarce, it is crucial that businesses have a clear understanding of the different types of financing options available.

Having a business plan and finding your niche market is the first hurdle - raising money to make your business succeed can be an even bigger struggle. Fundamentally there are two categories of financing options for businesses: internal and external. Internal capital originates from within the enterprise while external comes from peripheral sources. The various types of financing options within each category are outlined in Figure 1 below. 


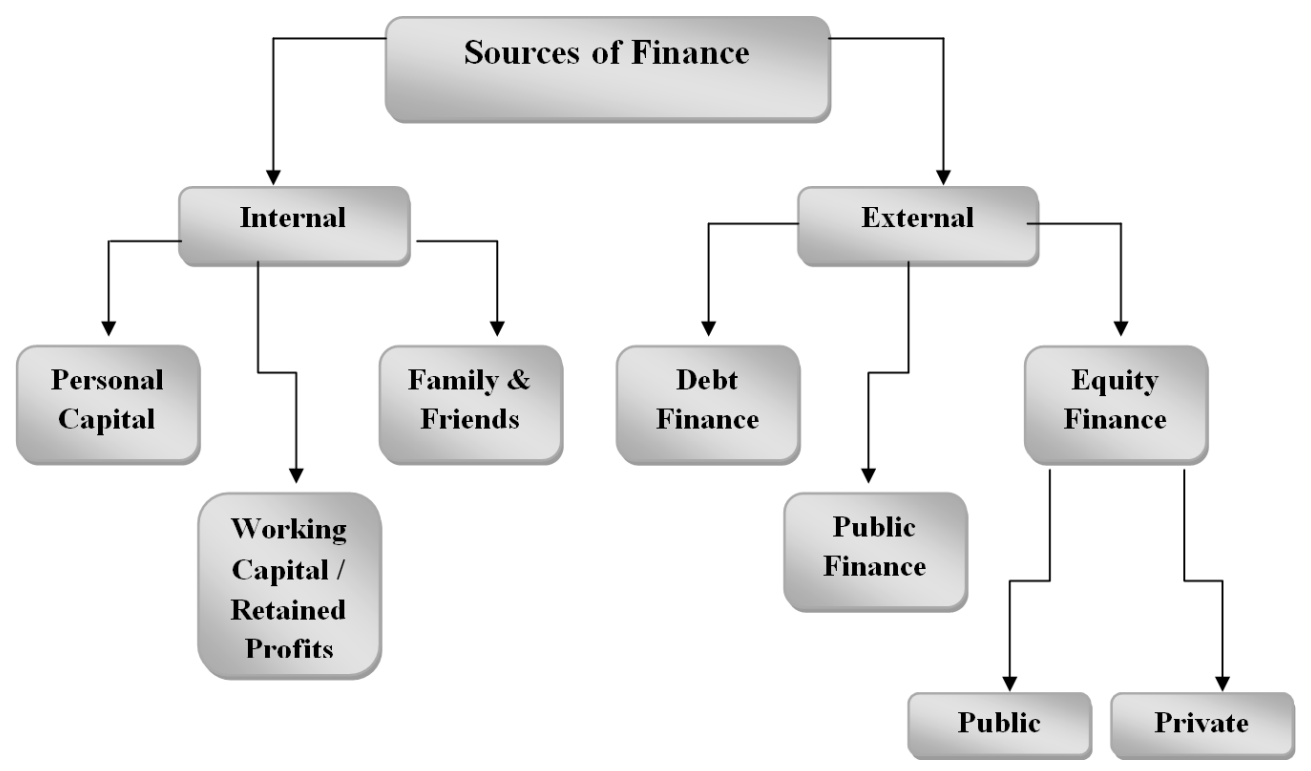

Figure 1: Sources of Finance

One type of internal funding is personal capital, where the entrepreneur invests his/her own money into the business or invests by foregoing his/her salary. Financing of a business therefore, often begins with the entrepreneur investing personal capital into setting up the business. Typical personal assets can include cash, shares, house and land to name a few. For example, Steve Jobs and Steve Wozniak, founders of Apple, started the company with $\$ 1,300$ in personal capital when Steve Jobs sold his Volkswagen micro-bus and Steve Wozniak sold his Hewlett-Packard scientific calculator. To finance additional growth, an entrepreneur may obtain capital from 'family and friends' who, as a group, will generally invest relatively small amounts. A third source of internal funds is retained profits (or earnings) which is income not paid out but instead reinvested into the business. However, businesses need to be up and running before they will have retained earnings to utilise. An alternative here would be working capital. This is essentially the cash required for the dayto-day running of the business. When larger amounts of capital are needed, entrepreneurs can attempt to obtain funding from external sources.

Externally, there are three options for raising capital. Firstly, there are various sources of debt. For example, a business loan or mortgage is a bank loan guaranteed for use by a business. Other sources of debt include business overdrafts, trade credit, leasing and hire purchase. Debt factoring (or invoice discounting) is also an option and involves a business essentially selling their debtor books (i.e., what customers owe) to a bank or financial institution which then advance funds on that basis.

Another source of external capital is public finance from government funded programmes. County Enterprise Boards provide various forms of financial assistance, including business priming grants, expansion/development grants and feasibility/innovation grants. Enterprise Ireland provides financial assistance to businesses in the form of grants. For example, 
the feasibility study grant is available to assist businesses in investigating the viability of manufacturing a new product or process or to develop a new service. Enterprise Ireland also run an Innovation Voucher scheme, which will be open from 1st to 31st October 2010 and provides $€ 5,000$ for assistance in research. There are numerous such support programmes available from public bodies throughout Ireland.

The third external option is equity finance, a method of financing in which a business receives money in exchange for ownership. Raising equity capital is very different from raising debt, such as a bank loan. For example, banks usually require security such as a charge over assets of the business, will charge interest on a loan and seek repayment. Equity capital is invested in exchange for a share in the business and, as shareholders, the equity investors' returns are dependent on the growth and profitability of the business. One of the main benefits of equity finance, particularly in comparison to debt, is that investors assume the risk - if the business fails they lose their money. An equity investment is unsecured, fully at risk and usually does not have defined repayment terms.

Modern equity capital has its origins in America. In 1946 Georges Doriot, a professor at Harvard University, created American Research and Development (ARD) together with Karl Compton, president of Massachusetts Institute of Technology, Merrill Griswold, chairman of Massachusetts Investors Trusts, and Ralph Flanders, president of the Federal Reserve Bank of Boston. ARD was created to raise funds from individuals and college endowments and invest in start-ups in technology-based manufacturing. Now, over half a century later, equity has become the form of funding associated with entrepreneurial startups, especially in high-technology industries like biotechnologies, computer hardware and software, e-commerce, information technology and telecommunications. Many of today's most successful corporations were financed, in part at least, by equity, including Irish company Lily O'Brien's Chocolates, along with Amazon, Dell, e-Bay, Google, Intel and Yahoo to name a few. There are numerous forms of equity financing available to entrepreneurs.

The main source of equity is venture capital. This is the provision of finance for growth and expansion to companies with underdeveloped or developing products, usually at an early stage in their corporate lifecycle, or the provision of development capital to mature companies at a later stage. Venture capital is an investment made by professional investors, known as venture capitalists, who invest capital on behalf of third parties. Venture capitalists raise money from third parties such as insurance companies, banks, pension funds and private investors and, in Ireland, venture capitalists raise significant capital from government sources, such as Enterprise Ireland. With the capital raised venture capitalists form a fund and, during the fund's life, make equity investments. Venture capitalists often take an active role in the businesses they invest in, mentoring and monitoring investees. As described by Sean Gallagher of Dragon's Den "Banks give a loan, and then ask for interest payments. VCs [Venture Capitalists] make an investment and then they provide expertise and guidance". 
Angel financing also represents an important source of equity finance. Business angels are wealthy individuals, many of them former entrepreneurs, who invest their own capital in emerging companies. Angels generally invest in young companies, at an early stage in their development, and can invest alone or as part of a group, usually in amounts that can range from $€ 10,000$ to $€ 500,000$. For example, in its early stages Amazon received a total of $\$ 54,400$ from two angels separately and $\$ 937,000$ from an angel syndicate comprised of twenty angels. Evidence suggests that in most vibrant entrepreneurial markets angel finance is the most significant, frequent and critical source of early-stage financing.

Public equity through government programmes is another source of equity. The Irish Government is actively involved in the equity financing of domestic businesses. The Business Expansion Scheme (BES) is one programme. The BES is a source of early-stage financing and has been in existence since 1984. The scheme allows an investor to obtain income tax relief on investment up to a maximum of $€ 150,000$ per annum. Enterprise Ireland also offers equity financing for manufacturing or service companies and high-potential businesses. Enterprise Ireland fund a number of equity programmes through its 'Seed and Venture Capital Programme'. The programme has promised $€ 175$ million to fund eight venture capital funds, which are in turn raising multiples of this amount from private investors.

Finally, corporate equity programmes provide capital to innovative, small companies, usually at an early stage in their development. For example, Intel Corporation and Johnson \& Johnson both operate venture investment funds which focus on making equity investments in young innovative companies. Corporate venture capital involves a subsidiary of a large company making an equity investment in a small, usually young, innovative company.

\section{Ireland's Equity Market}

The Irish equity market has grown tremendously in recent years. In 1997, total equity investments into companies based in Ireland totalled $€ 39$ million. By 2007 this had increased to $€ 226$ million, an increase of approximately 580\%. Interestingly, Ireland appears to have weathered the fundraising storm brought about by the financial crisis better than neighbouring UK and Europe. Equity investment continued to rise in 2009 in Ireland, totalling €288 million, increasing by over $18 \%$ on 2008 investments of $€ 243$ million. Across Europe equity investment activity has slowed. According to the European Venture Capital Association the amount invested by equity firms fell by $27 \%$ in 2008 to $€ 54.4$ billion and reached only $€ 23$ billion in 2009 .

Ireland has created a strong domestic equity industry over the past decade and the industry has experienced strong growth. Equity is an important source of funding for new, innovative businesses. The ability to weather the current downturn and uncertainty across fi- 
nancial markets is remarkable. The European Commission recently stated that the current financial crisis, difficulties in accessing bank finance and a rapidly deteriorating European economy have heightened the need to establish an adequate equity source of financing for European innovative enterprises. It is crucial that the Irish equity market continues to attract capital from investors in order to ensure that innovative businesses have access to the funding they need to start and grow.

\section{Conclusion}

According to the Global Entrepreneurship Monitor, Ireland has become one of the most entrepreneurial countries in the world. In addition, recessions often present great opportunity for innovative sectors of the economy. Entrepreneurs tend to emerge, with redundancies and downsizing providing experienced professionals who decide to start their own business. This can result in a new generation of start-ups which, according to Enterprise Ireland, are critical for future growth. However, businesses can only develop and grow if they have access to finance. The process of raising capital is complex and those outside the industry can have difficulty understanding financing options. With the Irish economy reeling from the banking crisis and property crash it is pertinent that sources of funding currently available to businesses are understood and investigated. Equity finance has become an increasingly prevalent method of financing businesses in Ireland and worldwide. The Irish equity industry has grown tremendously since the mid-1990s. Television shows such as 'Dragons' Den' highlight the growing popularity of equity financing. In the current economic climate, equity capital provides entrepreneurs with an opportunity to generate investment and seed capital to establish their business. There has been limited examination of the funding of businesses in Ireland. This research examines the financing of Irish businesses, providing a more in-depth understanding of the complexities of the Irish market for finance.

Jane Power is a student in the Department of Economics under the supervision of Dr. Bernadette Power and Dr. Geraldine Ryan. The author would like to acknowledge funding from the Irish Research Council for the Humanities and Social Sciences (IRCHSS) 